\title{
Differential Induction of a Peroxidase Gene Family During Infection of Rice by Xanthomonas oryzae pv. oryzae
}

\author{
Jaishree M. Chittoor, Jan E. Leach, and Frank F. White \\ Department of Plant Pathology, Throckmorton Hall, Kansas State University, Manhattan 66506, U.S.A. \\ Received 31 March 1997. Accepted 18 June 1997.
}

Induction of peroxidase has been correlated with resistant interactions between rice and Xanthomonas oryzae pv. oryzae. To assist in analysis of the role of rice peroxidases in plant defense against the bacterial pathogen, three peroxidase genes, POX22.3, POX8.1, and POX5.1, were identified from a rice cDNA library that was constructed from leaves of plants undergoing a resistant reaction. These genes were highly similar in nucleic acid and amino acid sequences and belonged to a gene family. The three genes showed differential expression in infiltrated rice leaves during pathogen interactions and mechanical stress. Only two peroxidase genes, POX8.1 and POX22.3, were predominantly expressed during resistant interactions. These two genes also were expressed during susceptible interactions, but induction was delayed compared with resistant interactions. POXgX9, a fourth peroxidase gene that was isolated from a genomic library, is adjacent to POX22.3 in the rice genome and has greater than $90 \%$ similarity in nucleotide and amino acid sequence identity to POX22.3. Interestingly, POXgX9 was expressed only in the roots of rice plants. While POX22.3 was expressed in both leaves and roots, POX8.1 and POX5.1 were not detected in roots but were induced in leaves by mechanical wounding at different times after treatment. POX22.3, POX8.1, and POX5.1 were estimated to be present in single copies in rice haploid genome. These results indicate that different members of the rice peroxidase gene family are distinctly regulated in response to various environmental cues.

Additional keywords: avirulence, avrXa10, bacterial blight.

Activation of a variety of enzymes occurs during resistant interactions of pathogens with plants, although what critical role, if any, each enzyme plays in the limitation of pathogen growth remains unclear. One group of enzymes whose activities are induced early during resistance are extracellular peroxidases (EC 1.11.1.7, $\mathrm{H}_{2} \mathrm{O}_{2}$ oxidoreductase). Increased peroxidase activity has been observed in a number of resistant

Corresponding author: Frank F. White; Telephone: (913) 532-6176; Fax: (913) 532-5692; E-mail: fwhite@ plantpath.ksu.edu

Nucleotide and/or amino acid sequence data are to be found at GenBank as accession numbers AF014467 (POX22.3), AF014468 (POX8.1), AF014469 (POX5.1), AF014470 (POXgX9), and AF014471 (POX3006). interactions involving plant-pathogenic fungal and bacterial interactions (Flott et al. 1989; Schweizer et al. 1989; Graham and Graham 1991; Reimers et al. 1992; Young et al. 1995) as well as during Rhizobium-legume symbioses (Salzwedel and Dazzo 1993). Increases in activities of specific extracellular peroxidases are spatially and temporally associated with decreases in the rate of pathogen multiplication and spread (Reimers et al. 1992; Guo et al. 1993), suggesting an active role for peroxidase in resistance.

Peroxidases are heme-containing glycoproteins that catalyze the oxidation of a variety of organic and inorganic substrates at the expense of $\mathrm{H}_{2} \mathrm{O}_{2}$. Peroxidases have a number of physiological functions that may contribute to resistance, including oxidation of hydroxy-cinnamyl alcohols into free radical intermediates (Gross 1980), phenol oxidation (Schmid and Feucht 1980), polysaccharide cross-linking (Fry 1986), cross-linking of extension monomers (Everdeen et al. 1988), and lignification (Grisebach 1981; Walter 1992). Increased peroxidase activity has been correlated with deposition of phenolic materials into plant cell walls during race-specific resistant responses (Graham and Graham 1991; Reimers and Leach 1991), consistent with the proposal that the construction of rigid cross-links and deposition of lignin during secondary cell wall development may limit pathogen ingress and spread in these interactions (Ride 1983; Tiburzy and Reisener 1990). Alternatively, reactive compounds associated with the processes of lignification may inhibit pathogen growth.

Despite the correlative evidence for the involvement of peroxidase activity with resistance, a specific role for peroxidase has not been demonstrated. One difficulty has been that peroxidases are encoded by closely related multigene families and, within the gene family, few to many of the genes may contribute incrementally to the resistance phenotype. For example, additional peroxidases were proposed to substitute in tomato for a highly anionic pathogen- and wound-induced peroxidase whose activity was abolished in antisense transgenic plants (Sherf et al. 1993). Alternatively, individual members of the family may be specialized for resistance in general or to particular pathogens. The induction patterns of a number of plant peroxidase genes have been studied during pathogen infection (Scott-Craig et al. 1995; El-Turk et al. 1996; Baga et al. 1995; Harrison et al. 1995; Vera et al. 1993; Reimmann et al. 1992; Thordal-Christensen et al. 1992; Rebmann et al. 1991; Schweizer et al. 1989). Two genes in barley were induced in resistant interactions with Erysiphe 
graminis f. sp. hordei (Thordal-Christensen et al. 1992) and peroxidase gene expression in tomato was shown to be induced differentially in resistant and susceptible lines by elicitors of the fungal pathogen Verticillium albo-atrum (Mohan and Kolattukudy 1990). The later studies focussed on the expression of peroxidase genes per se. They did not characterize the expression of individual genes from the total complement of peroxidase genes in resistant and susceptible interactions with a given plant-pathogen interaction.

We are studying the role of peroxidases in resistant interactions between rice and Xanthomonas oryzae pv. oryzae, which causes bacterial blight disease. The resistance response in rice to this pathogen is typical of a gene-for-gene interaction (Ellingboe 1976; Flor 1955; Mew 1987; Hopkins et al. 1992) and provides an excellent system to study the host responses that occur during pathogen challenge. Increased peroxidase activity was observed during both resistant and susceptible interactions in rice. However, induction was delayed considerably in susceptible interactions, compared with the resistant reaction (Reimers et al. 1992; Young et al. 1995). Although numerous isoforms of peroxidase occur in rice, the induction of only three isozymes was detected during resistant interactions (Reimers et al. 1992). Our goal was to identify pathogen-induced peroxidase genes and characterize their induction patterns during the resistance response. Here, we report that out of the large number of peroxidase genes in rice, the mRNA of only two genes appeared in abundance following challenge by avirulent strains of $X$. oryzae pv. oryzae; one of these two also was wound-inducible. Other peroxidase homologs were highly related on the basis of sequence similarities and yet were not pathogen- or wound-induced. Thus, despite close similarities, each peroxidase gene displayed unique regulatory behavior.

\section{RESULTS}

\section{Isolation of induced peroxidase genes of rice.}

A 300-bp fragment (pPOX3006) was amplified from IRBB10 genomic DNA with primers designed from previously characterized peroxidases and used as a probe of IRBB10 genomic DNA to assess the complexity of peroxidase-containing sequences (see Materials and Methods). DNA gel blot analysis of HindIII-, XhoI-, and PstI-digested IRBB10 genomic DNA with the 300-bp insert showed that the fragment hybridized most strongly to two groups of HindIII fragments of approximately 6.5 and $8.0 \mathrm{~kb}$, respectively, and two HindIII fragments of intermediate intensity at 9 and $3.8 \mathrm{~kb}$ (Fig. 1, lane 1). Six to eight bands of lower intensity also were observed. Major bands representing fragments of 4.5, 5.5, and $9.0 \mathrm{~kb}$ and a variety of less intense bands were observed in the XhoI digest (Fig. 1, lane 2). Major bands of 1.5, 2.3, 3.4, 4.0, and $10 \mathrm{~kb}$ and numerous additional faint bands were observed in the Pst I digests (Fig. 1, lane 3).

RNA gel blot analysis with pPOX3006 as a probe indicated that peroxidase genes were induced strongly by $12 \mathrm{~h}$ in a resistant interaction (data not shown). To isolate pathogeninducible members of the peroxidase gene family, as detected by pPOX3006, we screened a cDNA library produced from mRNA isolated from rice $12 \mathrm{~h}$ after infiltration with an aviru-

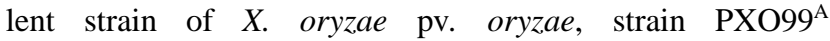
(pBUavrXa10-2). Initially, five cDNA clones that hybridized to pPOX3006 were retrieved from the library and characterized. Sequence analysis revealed that each contained peroxidase-related sequences. The 3' untranslated regions of four clones were identical and probably represented a single gene or group of near-identical genes. One clone of this group was designated POX8.1. The fifth clone possessed a distinct $3^{\prime}$ untranslated region and was designated POX22.3. Of 484 plaques (from the approximately $0.7 \times 10^{6}$ phage) that hybridized to the insert of pPOX3006, 334 (69\%) hybridized with the POX8.1 3' untranslated sequence and 89 (18.4\%) hybridized with the POX22.3-specific probe.

Other peroxidase cDNA sequences in the rice pathogeninduced cDNA library were detected by screening replicated membranes with POX3006 and the 3' untranslated regions of POX8.1 and POX 22.3. Sixty-one plaques hybridized with pPOX3006 (12\% of the original 484 plaques) and did not hybridize with the $3^{\prime}$ untranslated probes for POX8.1 and POX22.3. Insert DNA from one of these cDNA clones, designated POX5.1, did not hybridize with gene-specific probes for POX8.1 or POX22.3 and represented another unique gene based on the putative 3' untranslated region. Twenty-four of 61 remaining plaques hybridized to the $3^{\prime}$ untranslated region of POX5.1. The sequence of one of the 37 remaining clones was identical to POX22.3 but was truncated and did not contain the $3^{\prime}$ untranslated region. Thirty-six clones remain uncharacterized.

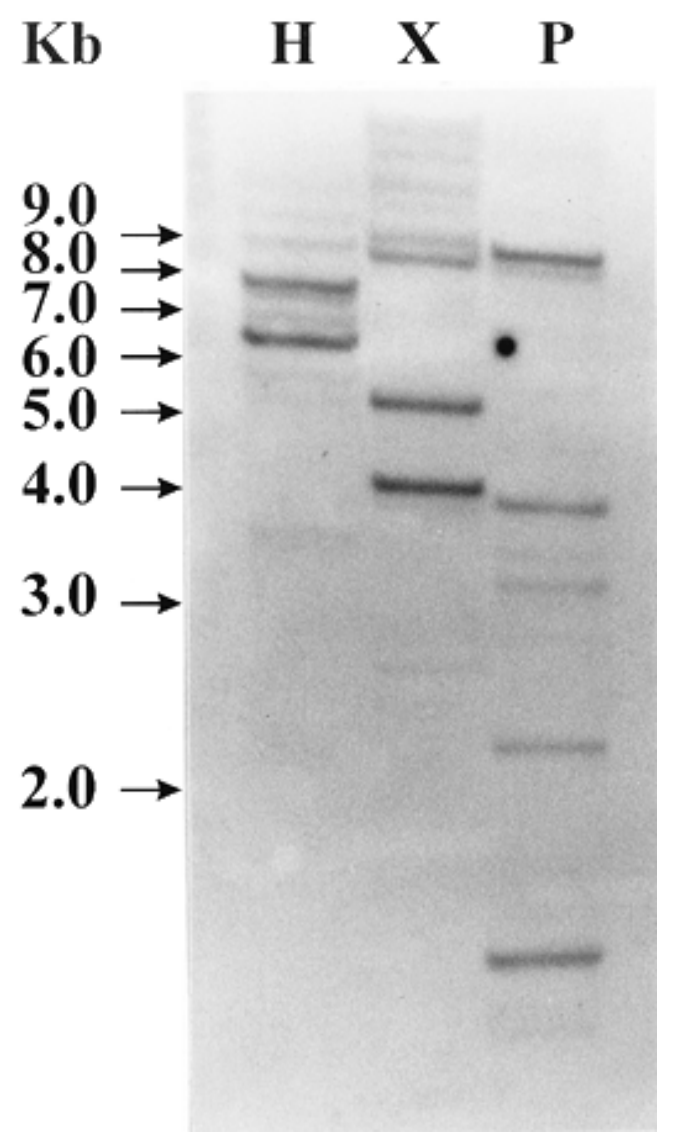

Fig. 1. Southern blot analysis of peroxidase sequences in rice. Ten micrograms of IRBB10 DNA was digested with HindIII (H), XhoI (X), or PstI (P), separated in a $0.7 \%$ agarose TAE (0.04 M Tris-acetate, $0.001 \mathrm{M}$ EDTA) gel, and blotted to nylon membranes. The blot was hybridized with the 300-bp radiolabeled insert from pPOX3006. 
The complete nucleotide sequences for POX8.1, POX22.3, and POX5.1 were determined. A fourth peroxidase gene (POXgX9) was subsequently identified from a rice genomic library and sequenced. The isolation of the genomic clone will be described in a separate report. The sequence analysis revealed that the three cDNA clones had insert sizes ranging from 1,221 to $1,385 \mathrm{bp}$ and, from the sequence comparison presented below, they represented full-length peroxidase coding sequences. The nucleotide sequences of the coding regions of the rice peroxidases were very similar before the stop codon; no sequence similarity was found between the four rice peroxidase genes in the $3^{\prime}$ untranslated regions (Fig. 2).

\section{Sequence comparison.}

An alignment of the deduced amino acid sequences of the genes and several homologs revealed that each potentially encoded proteins of approximately the same size (Fig. 3). The deduced amino acid sequence lengths for POX8.1, POX22.3, and POX5.1 ranged from 314 to 317 residues, while the genomic clone POXgX9 encoded a protein of 314 amino acid residues (Table 1). The estimated molecular mass of the four proteins ranged from 30 to $31 \mathrm{kDa}$ (Table 1). POX8.1 and POX5.1 coded for previously unreported peroxidase genes on the basis of the sequence comparison, while POX22.3 was nearly identical to a previously characterized rice gene (OSPER; GenBank accession no. X66125). The deduced amino acid sequences for the POX22.3 and OSPER clones differed only at two residues (234 to 235 ; Fig. 3), and the nucleotide sequences of the respective $3^{\prime}$ untranslated regions were identical (not shown). The rice genomic clone POXgX9 was identical to the protein coding sequence of RICPERX from root cDNA library (M. Hori, unpublished; GenBank accession no. D16442).

The deduced amino acid sequences of the four full-length peroxidases were greater than $81 \%$ similar and $71 \%$ identical (Table 2). POX22.3 and POXgX9 were $90 \%$ identical and 92\% similar, and POX22.3 and POX3006 were $89 \%$ identical and $92 \%$ similar (Table 2). Five amino acid residues that were present in POX8.1 were absent in the other three full-length rice peroxidase sequences (positions 77 to 81; Fig. 3). POX3006 represented the partial sequence of a putative fifth gene and lacked six nucleotides representing two amino acid residues (between 33 and 34; Fig. 3). Putative signal peptide cleavage sites were identified in the coding sequences of all the full-length clones (POX8.1, POX5.1, POX22.3, and POXgX9; Fig. 3). No clear peroxisomal targeting signal se-

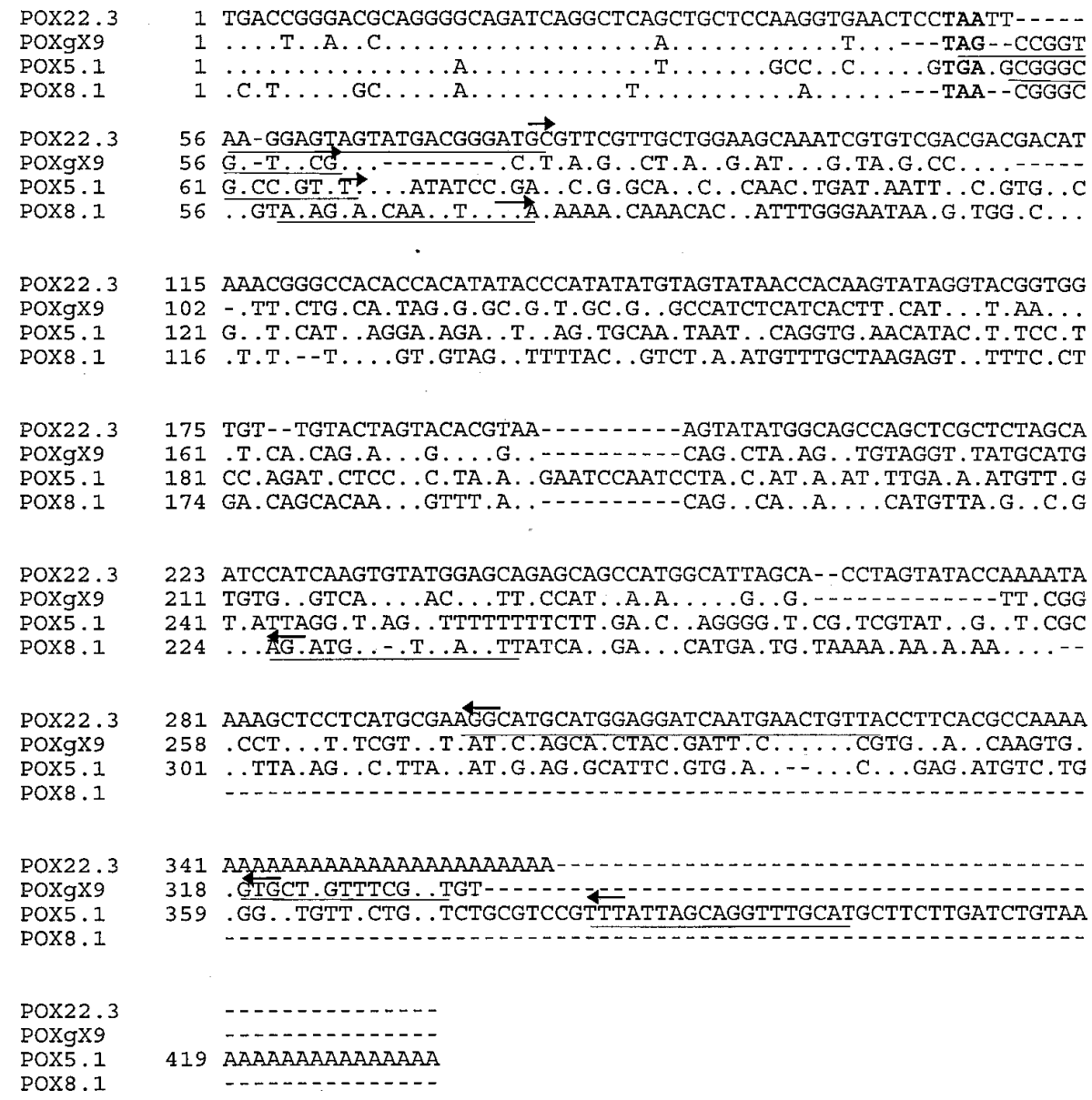

Fig. 2. Nucleotide sequence comparison of the $3^{\prime}$ untranslated regions of four rice peroxidase clones. Nucleotide sequences of POXgX9, POX5.1, and POX8.1 were aligned with the $3^{\prime}$ untranslated region of POX22.3. Dots indicate identity, and dashes represent spaces that were introduced to maximize the alignment. Stop codons are shown in bold. Sequences of the primers for amplification of the 3' untranslated regions are underlined, and the arrows indicate the direction of amplification. 
quences were detected. Therefore, the four peroxidases were predicted to be extracellular in location. The predicted amino acid sequences of the rice peroxidases were considerably divergent from the amino acid sequence of horseradish peroxidase $\mathrm{C}$ except in the three highly conserved $\mathrm{B}, \mathrm{D}$, and $\mathrm{F}$ helices (HRPC1; Fig. 3), which are common to plant peroxidases and reported to be important in catalysis and protein folding (Welinder 1985).

\section{Differential induction of rice peroxidase genes during pathogen challenge.}

Expression of rice peroxidase genes following infiltration of

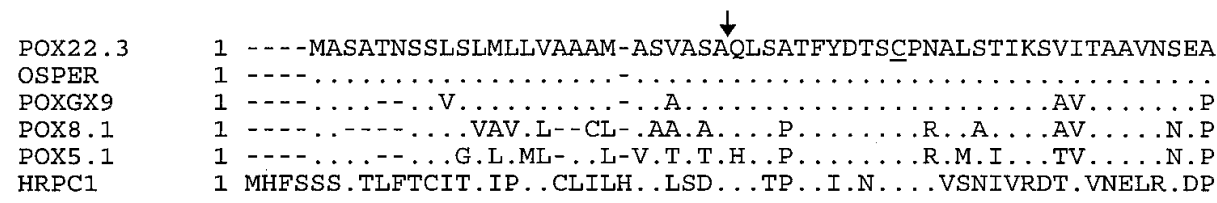

$\operatorname{POX} 22.3$ OSPER POXGX9 POX8.1 POX 5.1 HRPC1

POX22.3 111 CNQTVSCADILILVAARDSVVALGGPSWTVLLGRRDSTTAS-EALANTDLPAPSSSLAELI

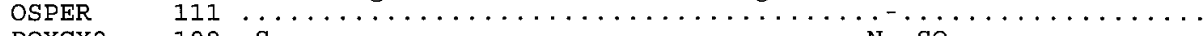

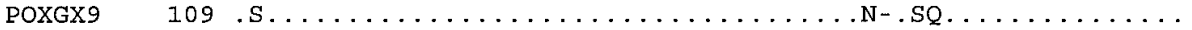

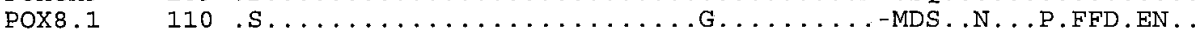

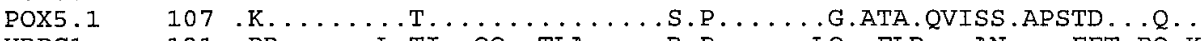

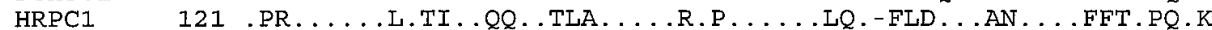

\section{$\mathbf{F}$}

POX22.3. 170 GNFSRKGLD-ATDMVALSGAHTIGQADQCQNFRDRIYN------ETNIDSAFATQRQANC

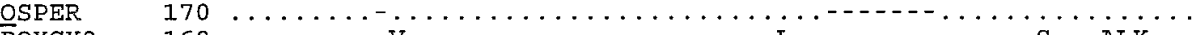

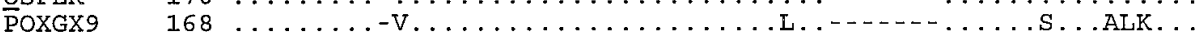

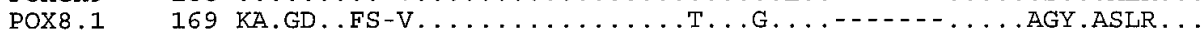

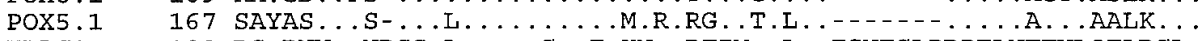
HRPC1 180 DS.RNV..NRSS.I.....G. .F.KN. .RFIM. .L. .FSNTGLPDPTLNTTYYLQTLRGL.

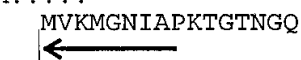

Fig. 3. Comparison of predicted protein sequences of five rice peroxidase genes. The predicted protein sequences from POX8.1, POX5.1, POX3006, OSPER (Reimmann et al. 1992; GenBank accession no. 20285), POXgX9, three peptides regions of PO-C1 (Young et al. 1995), and horseradish peroxidase (HRPC1; GenBank accession no. M37156) (Fujiyama et al. 1988) were aligned with POX22.3. Dots indicate sequence identity; dashes represent spaces introduced to maximize alignment. Horizontal lines represent conserved catalytic and distal heme binding domain (B), proximal heme binding domain (F), and central conserved domain (D) of unknown function (Welinder 1985). Horizontal arrows indicate primers, Cat2B and a3, used to amplify the insert in pPOX3006. Asterisks $(*)$ identify the two amino acid residues in OSPER that vary from POX22.3. Downward arrow $(\downarrow)$ represents potential signal peptide cleavage site. Invariant histidine (sites involved in heme binding) and cysteines (involved in formation of disulfide bridges) are underlined. Arp-Arg residues (involved in salt bridge formation) are circled (Welinder 1985). Lowercase letters in PO-C1 signify uncertainties; x, residues not identified. 
rice seedling leaves with either the virulent or avirulent pathogens or following mock-inoculation with water was monitored over a 72-h period. Of the four genes for which gene-specific 3 ' untranslated probes were available, only POX22.3 and POX8.1 mRNA accumulations were specific to the leaves of the plants that were infected with bacteria (Fig. 4). Signal intensity for POX22.3 and POX8.1 transcripts was greatest during the resistant interaction, with accumulation of POX8.1 transcripts preceding the accumulation of POX22.3 transcripts by $6 \mathrm{~h}$ (Fig. 4). Though POX22.3 mRNA was detected by $6 \mathrm{~h}$, the highest level was detected between 12 and $24 \mathrm{~h}$ post infiltration in the resistant reaction. By $48 \mathrm{~h}$, the transcript levels of both POX22.3 and POX8.1 had decreased to levels near those observed in uninoculated tissues (Fig. 4). The difference in transcript accumulation between POX8.1 and POX22.3 may be attributed to the observed increase in POX8.1 in the 6$\mathrm{h}$ sample from the mock-inoculated tissues (Fig. 4). The results indicated that some POX8.1 accumulation is elicited by the inoculation process. The level of signal with an actin probe indicated that the levels of total mRNA in each sample were similar (Fig. 4, lower panel).

Accumulation of POX22.3 and POX8.1 transcripts also was detected in RNA isolated from rice leaves undergoing a susceptible response. The susceptible response was initiated with $X$. oryzae pv. oryzae $\mathrm{PXO} 99^{\mathrm{A}}(\mathrm{pBU})$, which lacked the avrXa10 gene. The increase in POX22.3 was modest and gradual, with maximum signal detected at $36 \mathrm{~h}$ after inoculation (Fig. 4). Signals in RNA fractions isolated from leaves undergoing the susceptible interaction after $36 \mathrm{~h}$ were reduced, presumably because RNA migration from the wells was hindered due to the large population of bacteria and associated increase in polysaccharides in the tissues. Induction of POX22.3 gene also was observed between 36 and $48 \mathrm{~h}$ in susceptible interactions when the RNA was re-precipitated with lithium chloride (data not shown).

The POX8.1 gene showed a different pattern of induction in leaves during susceptible interactions, compared with POX22.3. Transcript levels increased from a low basal level at $0 \mathrm{~h}$ to a high level by $6 \mathrm{~h}$, comparable in intensity to the in-

Table 1. Relevant features of peroxidase sequences from rice

\begin{tabular}{|c|c|c|c|c|}
\hline \multirow[b]{2}{*}{ Sequence feature } & \multicolumn{4}{|c|}{ Peroxidase clones } \\
\hline & POX22.3 & POX8.1 & POX5.1 & POXgX9 \\
\hline Length (bp) & 1,308 & 1,221 & 1,385 & 1,310 \\
\hline Amino acid sequence length & 317 & 315 & 314 & 314 \\
\hline 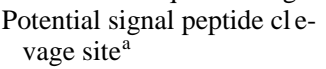 & 25 to 26 & 19 to 20 & 22 to 23 & 23 to 24 \\
\hline $\begin{array}{l}\text { Estimated molecular mass } \\
\text { of mature protein }(\mathrm{kDa})^{\mathrm{b}}\end{array}$ & 30.5 & 31.2 & 30.4 & 30.5 \\
\hline $\begin{array}{l}\text { Estimated pI for mature } \\
\text { protein }^{\mathrm{b}}\end{array}$ & 6.1 & 6.1 & 7.58 & 5.66 \\
\hline $\begin{array}{l}\text { Potential } N^{\prime} \text { glycosylation } \\
\text { sites }^{c}\end{array}$ & 5 & 2 & 4 & 6 \\
\hline Probable cellular loc ation $^{\mathrm{d}}$ & $\mathrm{E}$ & $\mathrm{E}$ & $\mathrm{E}$ & $\mathrm{E}$ \\
\hline $\begin{array}{l}\text { Length of the } 3^{\prime} \text { untrans- } \\
\text { lated region used as gene- } \\
\text { specific probe (bp) }\end{array}$ & 281 & 218 & 362 & 284 \\
\hline \multicolumn{5}{|c|}{$\begin{array}{l}\text { a Sequence analysis performed with SignalP (Neilson et al. 1997; Center } \\
\text { for Biological Sequence Analysis, Lyngby, De nmark). } \\
\text { b Sequence analysis performed with Peptidesort (GCG, Madison, WI) } \\
\text { c Sequence analysis performed with Peptidestructure (GCG) } \\
\text { d Sequence analysis performed with PSORT (Nakai, K. GenomeNet, } \\
\text { Kyoto, Japan) }\end{array}$} \\
\hline
\end{tabular}

duction of the transcript at $6 \mathrm{~h}$ in the resistant interaction, and decreased sharply by $12 \mathrm{~h}$ to a level that persisted through the end of the assay period (Fig. 4). As with POX22.3, transcript detection was obscured in the later time points, presumably as a consequence of accumulation of bacteria at the inoculation site. The level of POX8.1 transcripts after $6 \mathrm{~h}$ was lower in the susceptible interactions after $12 \mathrm{~h}$ when compared with the level in the resistant interaction, but was higher than the levels in the water-treated controls. As in the resistant interaction, a peak of POX8.1 transcript accumulation also was observed in the mock-inoculated controls (Fig. 4), indicating that accumulation at $6 \mathrm{~h}$ is due to the inoculation process.

Unlike the case with the POX22.3 and POX8.1 genes, an increase in POX5.1 mRNA was not observed during interaction with the pathogen. High levels of POX5.1 gene transcripts were detected at $0 \mathrm{~h}$ in all treatments, and the amount returned to near basal levels within $6 \mathrm{~h}$. Beyond $6 \mathrm{~h}$, the level of POX5.1 was only slightly elevated at 16 and $24 \mathrm{~h}$ in the resistant and susceptible interactions, compared with the mock-inoculation treatment. The pattern indicated that, similar to that of POX8.1, the accumulation of POX5.1 was attributable to the inoculation process, and, unlike POX8.1, very little accumulation could be attributed to the resistant interaction. No RNA specific for $\mathrm{POXgX9}$ was detected from rice leaves after any treatment (Fig. 4).

The induction of each gene by wounding was assessed by mechanically damaging rice leaves and probing for mRNA from each gene at 0,6 , and $12 \mathrm{~h}$ with the unique $3^{\prime}$ untranslated sequences (Fig. 5, lanes 1 to 3). Wounding did not induce detectable expression of POX22.3 or POXgX9 genes in leaves, whereas POX8.1 and POX5.1 transcripts were detected at high levels at 6 and $12 \mathrm{~h}$, respectively, in leaves following wounding (Fig. 5, lanes 2 to 3 ). In contrast to treatments involving infiltration with water or bacteria, POX5.1 levels were not detected immediately after wounding.

The developmental expression of the peroxidase genes was analyzed by probing RNA isolated from roots and leaves from 10-day-old uninoculated seedlings and newly expanded leaves from 3-month-old rice plants (Fig. 5, lanes R, SL, and OL). POX5.1 and POX8.1 gene expression was not detected in roots but was detected at low levels in the newly expanded

Table 2. Percentage similarities and identities between deduced amino acid sequences of rice peroxidases $^{\mathrm{a}}$

\begin{tabular}{|c|c|c|c|c|c|c|}
\hline \multirow{2}{*}{$\begin{array}{l}\text { Peroxidase } \\
\text { clones }\end{array}$} & \multicolumn{6}{|c|}{ Peroxidase clones } \\
\hline & POX22.3 & POX8.1 & POX5.1 & POXgX9 & $\overline{P O X 3006}$ & HRPC1 \\
\hline \multirow[t]{2}{*}{ POX22.3 } & 100.0 & & & & & \\
\hline & 100.0 & & & & & \\
\hline \multirow[t]{2}{*}{ POX8.1 } & 82.2 & 100.0 & & & & \\
\hline & 75.4 & 100.0 & & & & \\
\hline \multirow[t]{2}{*}{ POX5.1 } & 80.8 & 80.9 & 100.0 & & & \\
\hline & 73.2 & 70.9 & 100.0 & & & \\
\hline \multirow[t]{2}{*}{ POXgX9 } & 92.2 & 83.9 & 81.1 & 100.0 & & \\
\hline & 90.1 & 77.1 & 73.1 & 100.0 & & \\
\hline \multirow[t]{2}{*}{ POX $3006^{\mathrm{b}}$} & 92.2 & 81.4 & 81.4 & 85.3 & 100.0 & \\
\hline & 89.2 & 77.5 & 78.4 & 82.4 & 100.0 & \\
\hline \multirow[t]{2}{*}{ HRPC1 } & 55.2 & 55.9 & 56.1 & 56.5 & 50.5 & 100.0 \\
\hline & 44.0 & 42.2 & 44.6 & 44.0 & 35.9 & 100.0 \\
\hline
\end{tabular}

${ }^{a}$ Percent amino acid similarities are shown in row 1 and identities are shown in row 2.

${ }^{\mathrm{b}}$ POX3006 is the amino acid sequence for the partial sequence of the polymerase chain reaction product. 
leaves. POX22.3 gene transcript was detected at higher levels in leaves of older plants than in seedling leaves. The POXgX9 gene transcript was not detected in rice leaves. Expression of POXgX9 and POX22.3 peroxidase genes was detected at low levels in roots.

\section{Peroxidase gene analysis.}

The number of genomic fragments that cross-hybridized to each clone was analyzed by Southern hybridization with three restriction endonucleases. In addition, the copy number of the genes was estimated by reconstruction experiments in which known amounts of each gene were added to the genomic DNA. In both analyses, the $3^{\prime}$ untranslated regions were used as gene-specific probes. The total copy number of pPOX3006like sequences in rice genome was estimated with the 300-bp insert of pPOX3006. Analysis of HindIII-, XhoI-, and PstIdigested IRBB10 DNA revealed that each gene-specific probe hybridized strongly to one restriction fragment (Fig. 6). The POX8.1 and POX22.3 gene-specific probes both hybridized to 8-kb HindIII and 5.5-kb XhoI fragments, while in the PstI digest, the POX22.3 probe hybridized to a $4-\mathrm{kb}$ fragment and the POX8.1 probe hybridized to a 3.4-kb fragment (Fig. 6A and $\mathrm{B}$ ). The POX5.1 gene-specific probe hybridized to 7-kb HindIII, 10-kb XhoI, and 8.5-kb PstI fragments (Fig. 6C). The simple hybridization patterns for each probe suggested that each cDNA is represented as a single gene in the genome.

To provide a more accurate estimate of the copy number of each gene, HindIII-digested rice DNA was spiked with DNA from each clone. Linearized pPOX22.3 and pPOX8.1 were added to IRBB10 DNA at concentrations of $1,3,5$, and $10 \mathrm{M}$ equivalents of haploid rice genome. POX8.1 and POX22.3 each hybridized to a single HindIII fragment of $8 \mathrm{~kb}$ (Fig. 7A and $\mathrm{B}$, respectively). The hybridization intensities with all of the probes were similar to the intensity of the single copy control, and each gene was estimated to be present in one or two copies per haploid genome. POX5.1 was also found to be present in single copy. Similar results were found for POX5.1 (data not shown).

\section{DISCUSSION}

Peroxidase is involved in many plant developmental and environmental responses (Gaspar et al. 1982). Not surprisingly, peroxidase-related sequences have been shown to be present in multiple copies in a variety of plant genomes (El-Turk et al. 1996; Baga et al. 1995; Harrison et al. 1995; Thordal-Christensen et al. 1991) and, as demonstrated here, in rice. Sequences related to POX3006 in the region of the 6.5and $8-\mathrm{kb}$ fragments of the HindIII digest have been estimated to exist as a cluster of at least four genes (J. M. Chittoor, unpublished). The entire sequence of POX22.3, which contains the highly conserved domains in the amino-terminus half of the gene, also was used in Southern analysis and provided essentially the same pattern as POX3006 (data not shown).

$$
\text { R S W }
$$

\section{$\begin{array}{llllllllllllllllllllll}0 & 6 & 12 & 16 & 24 & 36 & 48 & 72 & 0 & 6 & 12 & 16 & 24 & 36 & 48 & 0 & 6 & 12 & 16 & 24 & 36 & 48\end{array}$}

POX8.1
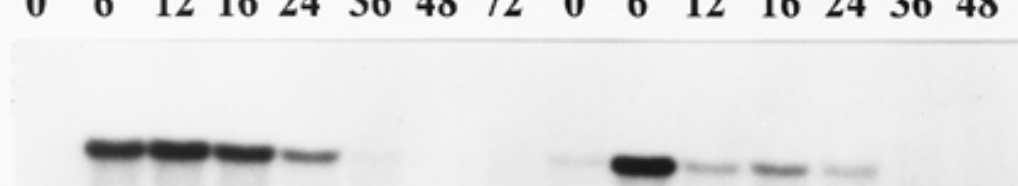
Thus, few if any peroxidase sequences related to the POX3006 family went undetected. Additional bands evident in genomic DNA, when probed with POX3006, may represent more distantly related sequences in the genome. Whether the detected fragments contain functional peroxidase genes remains unknown.

Our goal was to distinguish those peroxidase genes that were expressed during a resistance reaction from the many related genes in the genome as a first step to studying their contribution to disease resistance. Although several potential genes were detected in the rice genome by hybridization, only three different peroxidase cDNAs were isolated with the pPOX3006 probe. Two genes, POX8.1 and POX5.1, were previously uncharacterized. A third, POX22.3, is likely the same gene as OSPER (Reimmann et al. 1992), a peroxidase gene retrieved from a cDNA library constructed from rice that was challenged with a nonpathogenic strain of Pseudomonas syringae pv. syringae with a wheat peroxidase probe (GenBank accession no. X56011; Rebmann et al. 1991). Only two bases in the coding regions were different between the sequences of POX22.3 and OSPER; these could be the result of sequencing errors. The 3' untranslated regions, which might be expected to accumulate silent changes if several nearidentical genes were present, were identical.

The majority of peroxidase transcripts that accumulated during resistant and susceptible responses were attributed to only two genes, POX8.1 and POX22.3. POX5.1 was induced equally well in mock inoculations with water or bacteria. POX8.1, POX22.3, and POX 5.1 represented $92 \%$ of the cDNA clones from the resistant reaction cDNA library (69, 18 , and $5 \%$, respectively) and were estimated to be present in 1 or 2 copies per haploid genome. The copy number estimate

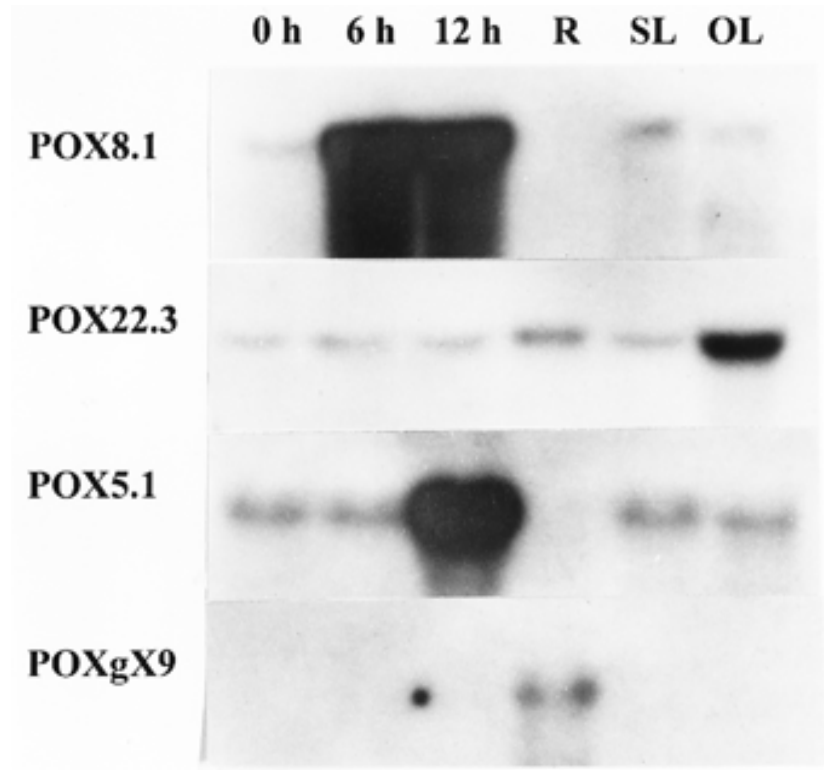

Fig. 5. Induction of genes for peroxidase by wounding and in rice leaves and roots. Total RNA was isolated at 0,6 , and $12 \mathrm{~h}$ following wounding of leaves from 10-day-old plants, roots (R), and leaves of 10-day-old (SL) and 3-month-old (OL) IRBB10 rice plants. The RNA (5 $\mu \mathrm{g}$ per lane) was subjected to Northern (RNA) analyses with radiolabeled probes amplified from the $3^{\prime}$ untranslated regions of each peroxidase gene (indicated at the left of each panel). for POX8.1 is further supported by sequence analysis. Sequence analysis of four clones related to POX8.1 from the cDNA library revealed identical $3^{\prime}$ untranslated ends (data not shown) suggesting that, if the gene is present in higher than one copy, a single copy is more active or the $3^{\prime}$ untranslated regions of the copies are identical in sequence. $\mathrm{POXgX9}$, which was similar in sequence to POX22.3 and POX8.1, was not induced in leaves after pathogen challenge. POXgX9 was isolated from a rice genomic library (J. M. Chittoor, unpublished data) and was not detected in the cDNA library.

Other peroxidase mRNA species may accumulate during the resistant response and were not detected in this study. In particular, a cDNA with sequences corresponding to PO-C1, which is a cationic peroxidase purified from inoculated tissue (Young et al. 1995) and had amino acid sequence similarity to the deduced peptide from POX3006 sequence, was not recovered from the library. Although evidence for induction of POC1 during resistance exists (Young et al. 1995), the gene may be expressed at a relatively low level at $12 \mathrm{~h}$, the time period at which our cDNA library was constructed, or the gene may be expressed in very few specific cells and, therefore, not represented in appreciable levels in the cDNA library. In the absence of the $3^{\prime}$ untranslated region of the probe, further analysis of the regulation of the PO-C1 gene was not attempted. Sequence variations between POX3006 and the other sequences will permit the design of polymerase chain reaction or oligonucleotide hybridization strategies to recover PO-C1 from either the remaining 36 POX3006-positive cDNAs or from the genomic library. Complete characterization of genomic clones of peroxidase sequences and an analysis of their expression patterns should permit the identification of

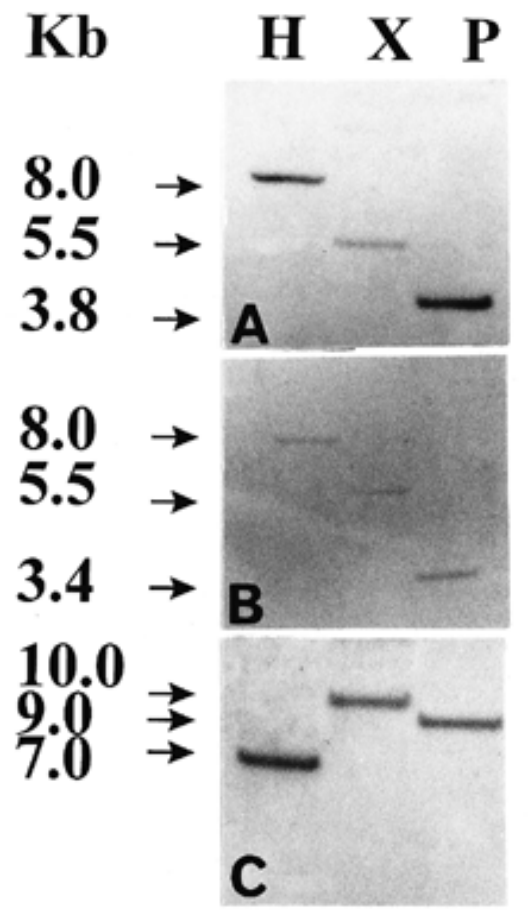

Fig. 6. Southern analysis of IRBB10 rice DNA with gene-specific probes for peroxidase. DNA was digested with HindIII (H), XhoI (X), or PstI (P) and hybridized to radiolabeled $3^{\prime}$ untranslated regions of (A) POX22.3, (B) POX8.1, and (C) POX5.1. 
the complete repertoire of genes. Note that this study examined the accumulation of peroxidase transcripts and did not assess actual peroxidase activity, and message accumulation may not directly reflect the contribution of each gene to the total peroxidase activity.

Each of the four rice peroxidase gene sequences that were examined in this study was determined to be differentially regulated in regard to accumulation in response to pathogen stress, wounding, and tissue specificity. POX22.3 and POX8.1 were both induced during the resistant interaction, yet were distinct in individual aspects of expression. POX8.1 accumulated more rapidly and was at or near the maximum steady-state level by 6 $\mathrm{h}$, whereas POX22.3 reached the maximum level by $12 \mathrm{~h}$. The difference in timing between the two genes may be due to the wound-inducibility of POX8.1. In all treatments-incompatible (resistant), compatible (susceptible), and mock-inoculation with water-POX8.1 was at maximum accumulation by $6 \mathrm{~h}$. However, in the compatible and mock-inoculation treatments, the peroxidase message returned to a low level by $12 \mathrm{~h}$. POX22.3 was not induced by wounding; thus, if POX8.1 and POX22.3 are triggered by the same signal during the incompatible response, the signal appears to occur after the wound signal for POX8.1 induction. Alternatively, resistant reactions may trigger a wound-signaling pathway, and POX8.1 may be strictly controlled by the wound-signaling process. Further experiments with wound-signaling inhibitors may allow us to distinguish between the induction of POX8.1 and POX22.3. POX8.1 and POX22.3 both have a low basal level of message in the seedling leaves that were used for inoculation. Unlike POX8.1, POX22.3 mRNA levels were elevated in 3-month-old leaves and present in seedling roots. Therefore, POX22.3 may function in development of both the leaves and roots, while the function of POX8.1 may be limited to wounding and other stresses.

In terms of regulation, POX5.1 represented another distinct

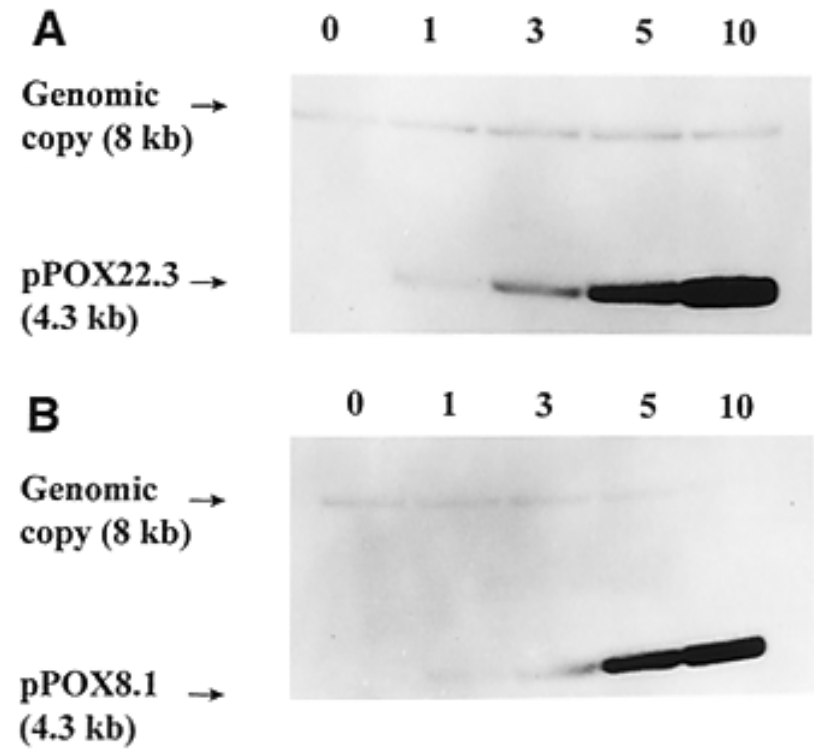

Fig. 7. Estimation of POX 22.3 and POX8.1 gene copy number. Linearized pPOX22.3 and $\mathrm{pPOX} 8.1$ containing the respective peroxidase genes were added at $1,3,5$, and $10 \mathrm{M}$ equivalents of haploid rice genome to $10 \mu \mathrm{g}$ of HindIII-digested rice IRBB10 genomic DNA. DNA gel blot analyses were performed with radiolabeled, gene-specific fragments from (A) POX22.3 and (B) POX8.1. class within the family of POX3006-related genes. Although induced at $12 \mathrm{~h}$ by mechanical wounding with a scalpel and at the $0 \mathrm{~h}$ sampling during infiltration with bacterial suspensions or water, POX5.1 did not respond to challenge by the pathogen either in a resistant or susceptible interaction. The observed difference in the timing of induction between wounding and infiltration could be due to subtle differences in the treatment. For example, differences in contact pressure or changes in ionic strength of the surrounding medium could occur after infiltration. The timing of the response of POX5.1 during wounding was slower than that of POX8.1, which increased by $6 \mathrm{~h}$ after the treatment.

Of the genes characterized here, POXgX9 was most similar to POX22.3 (approximately 90\% sequence identity at the amino acid and nucleotide level), and the two genes were immediately adjacent in the genome (J. M. Chittoor, unpublished data). POXgX9 expression was detected in roots and not in leaves. POX22.3 also was expressed in roots and, therefore, these genes may share some similarities in regulation. Induction of $\mathrm{POXgX9}$ in roots upon wounding or pathogen-induced stress was not studied.

The distinct expression characteristics of each of the four rice peroxidase genes is consistent with the general feature of multigene families in that the individual family members are often regulated under specific and different circumstances (ElTurk et al. 1996; Bell et al. 1986; Harker et al. 1990; Ryder et al. 1987; Koes et al. 1989). Peroxidase may be an extreme case of gene proliferation due to the diversity of situations in which the expression of the enzyme is required. Differential expression suggests that the peroxidase genes may have multiple cis-acting promoter elements to respond to different stimuli, possibly through various trans-acting factors. Thus, the presence or absence of cis-acting promoter regions or trans-acting factors in a particular cell would determine gene expression. In pea, for example, chalcone synthase (CHS) is encoded by a multigene family. Two CHS genes, CHS1 and CHS3, are expressed both in roots and petals. The trans-acting factors encoded by the regulatory loci a and a2 are required for their expression in petals but not roots (Almeida et al. 1989; Harker et al. 1990). Therefore, these genes contain multiple regulatory elements that control expression in particular environments. A structural and functional comparison of the peroxidase promoters will provide insight regarding the regulation of these genes.

Our studies have shown that POX22.3 was expressed at higher levels in the leaves of untreated older plants than in the leaves of seedling plants. An interesting question to address would be to determine if the increased presence of POX22.3 is a factor that contributes to the general increase in resistance of $X$. oryzae pv. oryzae as rice plants mature. One way of studying the function(s) of this family of peroxidases and the dynamics of their cellular regulation, especially during pathogen interactions, is by developing transgenic plants over-expressing or suppressing the expression of individual members or several members of this family. These studies are in progress.

\section{MATERIALS AND METHODS}

\section{Bacterial strains and media.}

Strains of Escherichia coli were cultured in Luria-Bertani medium (Miller 1972) at $37^{\circ} \mathrm{C}$. Strains of $X$. oryzae pv. 
oryzae, PXO99 ${ }^{\mathrm{A}}\left(\mathrm{pBU}\right.$ avrXa10-2), and $\mathrm{PXO} 99^{\mathrm{A}}(\mathrm{pBU})$ (Young et al. 1995) were grown in either nutrient broth (Difco Laboratories, Detroit, MI) or peptone sucrose medium (Karganilla et al. 1973) at $28^{\circ} \mathrm{C}$. The antibiotics carbenicillin and kanamycin were incorporated into the media as needed at 100 and 50 $\mu \mathrm{g} / \mathrm{ml}$, respectively. Bacteria were grown overnight with shaking, harvested by centrifugation, and resuspended in sterile water at $5 \times 10^{9} \mathrm{CFU}$ per ml prior to inoculation (Reimers and Leach 1991).

\section{Plant treatments and RNA isolation.}

Rice cultivar IRBB10 containing the XalO gene for bacterial blight resistance (Ogawa and Khush 1989) was cultivated in growth chambers as described (Reimers and Leach 1991). After 10 to 12 days after sowing and two leaves were fully expanded, the second leaf was infiltrated at multiple sites with bacterial suspensions $\left(5 \times 10^{9} \mathrm{CFU} / \mathrm{ml}\right)$ or with sterile water with a needle-less syringe. Wounding was achieved by scraping the leaf blade of the fully expanded second leaf with a scalpel. The treatment produced vertical cuts in some areas of the leaf blade surface. Following treatments, the plants were returned to the growth chamber and incubated under continuous light at $30^{\circ} \mathrm{C}$ and $75 \%$ relative humidity for $24 \mathrm{~h}$. At the end of the light period, the normal light regiment $(12 \mathrm{~h}$ light/12 h dark) was resumed. Infiltration of $X$. oryzae $\mathrm{pv}$. oryzae strain $\mathrm{PXO} 99^{\mathrm{A}}(\mathrm{pBUavrXa10}-2)$ containing avirulence gene avrXa10 into IRBB10 leaf blades resulted in a hypersensitive reaction characterized by development of dark brown, necrotic lesions at the infiltrated site (Reimers and Leach 1991). Infiltration of $X$. oryzae pv. oryzae strain $\mathrm{PXO} 99^{\mathrm{A}}(\mathrm{pBU})$ that lacks the $a v r X a 10$ resulted in a susceptible response (water-soaking).

Leaves were harvested for RNA isolation at $0,6,12,16,24$, 36,48 , and $72 \mathrm{~h}$ after infiltration with bacteria or water, or at 0,6 , and $12 \mathrm{~h}$ after wounding. RNA extraction was initiated within $30 \mathrm{~min}$ to $1 \mathrm{~h}$ after inoculation of the $0 \mathrm{~h}$ samples. Total RNA from the leaves were isolated immediately by guanidine thiocyanate extraction (Chomczynski and Sacchi 1987). Total RNA was similarly isolated from uninoculated seedling leaves and roots and from the newly emerged, fully expanded leaves of 3-month-old rice plants.

\section{Preparation of peroxidase probe.}

Two primers were designed from the conserved regions of previously reported peroxidase sequences (Scott-Craig et al. 1995) and a partial amino acid sequence for a purified pathogen-induced rice peroxidase (PO-C1) (Young et al. 1995). The nucleotide sequences of primers $\mathrm{Cat} 2 \mathrm{~B}$ and $\mathrm{a} 3$ are $5^{\prime}$-ATC GG(G/C) CAG GCG CAG TGC TC-3' and 5'-ATG TT(G/C) CCC ATC TTC ACC AT-3', respectively. Polymerase chain reaction was performed with approximately 100 to $200 \mathrm{ng}$ of IRBB10 DNA, $0.1 \mathrm{mM}$ each of dATP, dCTP, TTP, and dGTP (Sigma, St. Louis, MO), 2 units of Taq DNA polymerase (Promega, Madison, WI), $0.1 \mathrm{mM} \mathrm{MgCl}_{2}$, and $25 \mathrm{pmol}$ of each primer per $100-\mu l$ reaction. Amplification reactions consisted of 35 cycles of the following regime: $20 \mathrm{~s}$ at $94^{\circ} \mathrm{C}, 30 \mathrm{~s}$ at $45^{\circ} \mathrm{C}$, and $90 \mathrm{~s}$ at $72^{\circ} \mathrm{C}$. A 300 -bp polymerase chain reaction product was cloned into T-tailed pUC19 vector (Marchuk et al. 1990), resulting in clone pPOX3006. The insert was sequenced and found to be similar to other published peroxidase sequences. The 300-bp DNA insert was amplified by poly- merase chain reaction from pPOX3006, purified from agarose gels, and used as probe to screen the cDNA library.

All DNA manipulations were done by standard protocols (Sambrook et al. 1989) unless otherwise described. Plant DNA was isolated as described by Saghai-Maroof et al. (1984). DNA probes were labeled with $\left[{ }^{32} \mathrm{P}\right] \mathrm{dCTP}$ by random priming (Feinberg and Vogelstein 1983).

\section{Construction and screening of a cDNA library.}

For the construction of a pathogen-induced cDNA library, total RNA was isolated $12 \mathrm{~h}$ after infiltration of IRBB10 leaves with $X$. oryzae pv. oryzae $\mathrm{PXO} 99^{\mathrm{A}}(\mathrm{pBUavrXa10-2})$. Poly $(\mathrm{A})^{+}$-containing RNA was isolated by oligo(dT) cellulose chromatography (Sambrook et al. 1989). The cDNA was synthesized from poly $(\mathrm{A})^{+}$-enriched RNA with the ZAP-cDNA synthesis kit according to the supplier's instructions (Stratagene, La Jolla, CA). The ligated DNA was packaged with a lambda packaging kit (Epicenter Technology, Madison, WI), and the library was amplified in E. coli strain XL1-Blue (Stratagene) before screening. The plaques were transferred to nylon membranes (Magna NT, MSI, MA), UV cross-linked, and screened for hybridization with the radiolabeled insert from pPOX3006. Plaques that hybridized to POX3006 were purified by at least three rounds of re-plating and screening. Phagemids were excised from the phage following manufacturer's instructions (Stratagene).

\section{DNA sequence analysis.}

Both strands of insert DNA were sequenced by primer walking with a Sequenase Kit (United States Biochemical, Cleveland, $\mathrm{OH}$ ) or on a Model 373A DNA sequencer from Applied Biosystem (LOCATION). Sequence analysis was performed with Seqaid (D. Rhodes and D. Roufa, Kansas State University, Manhattan, KS) and GCG version 8.0 software package (GCG, Madison, WI), Boxshade 3.21 (M. Baron and K. Hofmann, Bioinformatics Group, Lasuanne), PSORT (Nakai, K. GenomeNet, Kyoto, Japan) and SignalP (Nielsen et al. 1997; Center for Biological Sequence Analysis, Lyngby, Denmark).

\section{Northern and Southern analysis.}

Total RNA $(\approx 5 \mu \mathrm{g})$ was denatured by heating at $65^{\circ} \mathrm{C}$ for 10 min in a denaturation buffer consisting of $50 \%$ formamide, 2.2 $\mathrm{M}$ formaldehyde, and 3.2 M urea. The RNA was separated on $1 \%$ agarose in TAE (0.04 $\mathrm{M}$ Tris-acetate, $0.001 \mathrm{M}$ EDTA) buffer and denatured for $15 \mathrm{~min}$ in $7.5 \mathrm{mM} \mathrm{NaOH}$ before transfer. RNA gel blot analysis was performed at least twice with total RNA isolated from two different experiments. The rice actin gene (pRAC2; McElroy et al. 1990) was used to indicate the relative amounts of mRNA used in each lane and experiments. IRBB10 genomic DNA $(10 \mu \mathrm{g})$ was digested with HindIII, XhoI, and PstI, and separated by gel electrophoresis through $0.7 \%$ agarose gels in TAE buffer. The gel was incubated for $15 \mathrm{~min}$ in $0.25 \mathrm{M} \mathrm{HCl}$ followed by 30 -min incubations in denaturation and neutralization solutions by the method of Southern (Southern 1975) as described in Sambrook et al. (1989). The nucleic acids were transferred to a nylon membrane (Magnagraph, MSI, Boston, MA) and were prehybridized and hybridized at $65^{\circ} \mathrm{C}$ in buffer containing 0.5 mM EDTA, 3\% sodium dodecyl sulfate, $250 \mathrm{mM} \mathrm{NaH} \mathrm{PO}_{4}$, and $300 \mu \mathrm{g}$ of sheared salmon sperm DNA per ml. The mem- 
branes were washed three times for 15 min each in $5 \times$ SSC ( $1 \times$ is $0.15 \mathrm{M} \mathrm{NaCl}, 0.015 \mathrm{M}$ sodium citrate).

\section{Copy number reconstruction.}

To determine the copy number of the different peroxidase genes, $10 \mu \mathrm{g}$ of HindIII-digested IRBB10 DNA was spiked with respective peroxidase $\mathrm{cDNA}$ at dilutions representing 1 $(100 \mathrm{pg}), 3(300 \mathrm{pg}), 5(500 \mathrm{pg})$, and $10(1 \mathrm{ng})$ copies per haploid genome $(450 \mathrm{Mb})$ (Arumuganathan and Earle 1991). DNA blot analysis was performed as described above. The blots were hybridized with respective $3^{\prime}$ untranslated regions of the cDNA clones, and the copy number was estimated following exposure of the autoradiogram.

\section{ACKNOWLEDGMENTS}

We thank Diana Pavlisko for preparation of the manuscript and Scot Hulbert and Sabbarat Muthukrishnan for reviewing the manuscript. J.M.C. was supported by a predoctoral Fellowship from the Rockefeller Foundation, and she wishes to thank the SPIC Science Foundation (Madras, India), Gary Toenniessen, John O'Toole, Joseph Bookmyer, and the Rockefeller Foundation for their support. This work was supported in part by USDA grant 94-37303-0548 and a grant from the Rockefeller Foundation to F.F.W. and J.E.L. This paper is contribution 97-369-J from the Kansas Experiment Research Station.

\section{LITERATURE CITED}

Almeida, J., Carpenter, R., Robbins, T. P., Martin, C., and Coen, E. S. 1989. Genetic interactions underlying flower color patterns in $\mathrm{An}$ tirrhinum majus. Genes Dev. 3:1758-1767.

Arumuganathan, K., and Earle, E. D. 1991. Nuclear DNA content of some important plant species. Plant Mol. Biol. Rep. 9:229-241.

Baga, M., Chibbar, R. N., and Kartha, K. K. 1995. Molecular cloning and expression analysis of peroxidase genes from wheat. Plant Mol. Biol. 29:647-662.

Bell, J. N., Ryder, T. B., Wingate, V. P. M., Bailey, J. A., and Lamb, C. J. 1986. Differential accumulation of plant defense gene transcripts in a compatible and incompatible plant-pathogen interaction. Mol. Cell. Biol. 6:1615-1623.

Chomczynski, P., and Sacchi, N. 1987. Single-step method of RNA isolation by acid guandinium thiocyanate-phenol-chloroform extraction. Anal. Biochem. 162:156-159.

El-Turk, J., Asemota, O., Leymarie, J., Sallaud, C., Mesnage, S., Breda, C., Buffard, D., Kondorosi, A., and Esnault, R. 1996. Nucleotide sequences of four pathogen-induced alfalfa peroxidase-encoding cDNAs. Gene 170:213-216.

Ellingboe, A. H. 1976. Genetics of host-parasite interactions. Pages 761-778 in: Encyclopedia of Plant Pathology, Physiological Plant Pathology. R. Heitefus and P. H. Williams, eds. Springer-Verlag, Heidelberg, Germany.

Everdeen, D. S., Kiefer, S., Willard, J. J., Muldoon, E. P., Dey, P. M., Li, X. B., and Lamport, D. T. A. 1988. Enzymic cross-linkage of monomeric extensin precursors in vitro. Plant Physiol. 87:616-621.

Feinberg, A. P., and Vogelstein, B. 1983. A technique for radiolabeling DNA restriction endonuclease fragment to high specific activity. Anal. Biochem. 132:6-13.

Flor, H. H. 1955. Host-parasite interaction in flax rust - its genetics and other implications. Phytopathology 45:680-685.

Flott, B. E., Moerschbacher, B. M., and Reisener, H. 1989. Peroxidase isoenzyme patterns of resistant and susceptible wheat leaves following stem rust infection. New Phytol. 111:413-421.

Fry, S. C. 1986. Cross-linking of matrix polymers in the growing cell walls of angiosperms. Annu. Rev. Plant Physiol. 37:165-186.

Fujiyama, K., Takemura, H., Shibayama, S., Kobayashi, K., Choi, J.-K., Shinmyo, A., Takano, M., Yamada, Y., and Okada, H. 1988. Structure of horseradish peroxidase isozyme c genes. Eur. J. Biochem. 173:681687.

Gaspar, T., Penel, C., Thorpe, T., and Greppin, H. 1982. Peroxidases: A Survey of Their Biochemical and Physiological Roles in Higher plants. University of Geneva Press, Geneva.

Graham, M. Y., and Graham, T. L. 1991. Rapid accumulation of anionic peroxidases and phenolic polymers in soybean cotyledon tissues following treatment with Phytophthora megasperma f. sp. glycinea wall glucan. Plant Physiol. 97:1445-1455.

Grisebach, H. 1981. Lignins. Pages 457-478 in: The Biochemistry of Plants. E. E. Conn, ed. Academic Press, New York.

Gross, G. G. 1980. The biochemistry of lignification. Adv. Bot. Res. 8: 25-63.

Guo, A., Reimers, P. J., and Leach, J. E. 1993. Effect of light on incompatible interactions between Xanthomonas oryzae pv. oryzae and rice. Physiol. Mol. Plant Pathol. 42:413-425.

Harker, C. L., Ellis, T. H. N., and Coen, E. S. 1990. Identification and genetic regulation of chalcone synthase multigene family in pea. Plant Cell 2:185-194.

Harrison, S. J., Curtis, M. D., McIntyre, C. L., Maclean, D. J., and Manners, J. M. 1995. Differential expression of peroxidase isogenes during the early stages of infection of the tropical forage legume Stylosanthes humilis by Colletotrichum gloeosporioides. Mol. Plant-Microbe Interact. 8:398-406.

Hopkins, C. M., White, F. F., Choi, S.-H., Guo, A., and Leach, J. E. 1992. Identification of a family of avirulence genes from Xanthomonas oryzae pv. oryzae. Mol. Plant-Microbe Interact. 5:451-459.

Karganilla, A., Paris-Natural, M., and Ou, S. H. 1973. A comparative study of culture media for Xanthomonas oryzae. Philipp. Agric. 57: 141-152.

Koes, R. E., Spelt, C. E., and Mol, J. N. M. 1989. The chalcone synthase multigene family of Petunia hybrida (V30): Differential, light-regulated expression during flower development and UV light induction. Plant Mol. Biol. 12:213-225.

Marchuk, D., Drumm, M., Saulino, A., and Collins, F. S. 1990. Construction of T-vectors, a rapid and general system for direct cloning of unmodified PCR products. Nucleic Acids Res. 19:1154

McElroy, D., Rothenberg, M., Reece, K. S., and Wu, R. 1990. Characterization of the rice (Oryza sativa) actin gene family. Plant Mol. Biol. $15: 257-268$.

Mew, T. W. 1987. Current status and future prospects of research on bacterial blight of rice. Annu. Rev. Phytopathol. 25:359-382.

Miller, J. H. 1972. Experiments in Molecular Genetics. Cold Spring Harbor Laboratory, Cold Spring Harbor, NY.

Mohan, R., and Kolattukudy, P. E. 1990. Differential activation of expression of a suberization- associated anionic peroxidase gene in near-isogenic resistance and susceptible tomato lines by elicitors of Verticillium albo-atrum. Plant Physiol. 92:276-280.

Nielsen, H., Engelbrecht, J., Brunak, S., and von Heijne, G. 1997. Identification of prokaryotic and eukaryotic signal peptides and prediction of their cleavage sites. Protein Eng. 10:1-6.

Ogawa, T., and Khush, G. S. 1989. Major genes for resistance to bacterial blight in rice. Pages 177-192 in: Bacterial Blight of Rice. Int. Rice Res. Inst., Manila, the Philippines.

Rebmann, G., Hertig, C., Bull, J., Mauch, F., and Dudler, R. 1991. Cloning and sequencing of cDNAs encoding a pathogen-induced putative peroxidase of wheat (Triticum aestivum L.). Plant Mol. Biol. 16:329-331.

Reimers, P. J., Guo, A., and Leach, J. E. 1992. Increased activity of a cationic peroxidase associated with an incompatible interaction between Xanthomonas oryzae pv. oryzae and rice (Oryza sativa). Plant Physiol. 99:1044-1050.

Reimers, P. J., and Leach, J. E. 1991. Race-specific resistance to Xanthomonas oryzae pv. oryzae conferred by bacterial blight resistance gene $\mathrm{Xa}-10$ in rice Oryza sativa involves accumulation of a lignin-like substance in host tissues. Physiol. Mol. Plant Pathol. 38:39-55.

Reimmann, C., Ringli, C., and Dudler, R. 1992. Complementary DNA cloning and sequence analysis of a pathogen-induced putative peroxidase from rice. Plant Physiol. 100:1611-1612.

Ride, J. P. 1983. Cell walls and other structural barriers in defense. Pages 215-236 in: Biochemical Plant Pathology. J. A. Callow, ed. Wiley-Interscience, New York.

Ryder, T. B., Hedrick, S. A., Bell, J. N., Liang, X., Clouse, S. D., and Lam, C. J. 1987. Organization and differential activation of a gene family encoding the plant defense enzyme CHS in Phaseolus vulgaris. Mol. Gen. Genet. 210:219-233.

Saghai-Maroof, M. A., Soliman, K. M., Jorgensen, R. A., and Allard, R. W. 1984. Ribosomal DNA spacer-length polymorphisms in barley: 
Mendelian inheritance, chromosomal location, and population dynamics. Proc. Natl. Acad. Sci. USA 81:8014-8018.

Salzwedel, J. L., and Dazzo, F. B. 1993. pSym nod gene influence on elicitation of peroxidase activity from white clover and pea roots by rhizobia and their cell-free supernatants. Mol. Plant-Microbe Interact. 6:127-134.

Sambrook, J., Fritsch, E. F., and Maniatis, T. A. 1989. Molecular Cloning: A Laboratory Manual. 2nd ed. Cold Spring Harbor Laboratory, Cold Spring Harbor, NY.

Schmid, P. S., and Feucht, W. 1980. Tissue-specific oxidative browning of polyphenols by peroxidase in cherry shoots. Gartenbauwissenschaft 45:68-73.

Schweizer, P., Hunziker, W., and Mosinger, E. 1989. cDNA cloning, in vitro transcription and partial sequence analysis of mRNAs from winter wheat (Triticum aestivum L.) with induced resistance to Erysiphe graminis f. sp. tritici. Plant Mol. Biol. 12:643-654.

Scott-Craig, J. S., Kerby, K. B., Stein, B. D., and Somerville, S. C. 1995. Expression of an extracellular peroxidase that is induced in barley (Hordeum vulgare) by the powdery mildew pathogen (Erysiphe graminis f. sp. hordei). Physiol. Mol. Plant Pathol. 47:407-418.

Sherf, B. A., Bajar, A. M., and Kolattukudy, P. E. 1993. Abolition of an inducible highly anionic peroxidase activity in transgenic tomato. Plant Physiol. 101:201-208.

Southern, E. M. 1975. Detection of specific sequences among DNA fragments separated by gel electrophoresis. J. Mol. Biol. 98:503

Thordal-Christensen, H., Brandt, J., Cho, B. H., Rasmussen, S. K., Gre- gersen, P. L., Smedegaard-Petersen, V., and Collinge, D. B. 1991. cDNA cloning and characterization of two barley peroxidase transcripts induced differentially by the powdery mildew fungus Erysiphe graminis. Physiol. Mol. Plant Pathol. 40:395-409.

Thordal-Christensen, H., Brandt, J., Cho, B. H., Rasmussen, S. K., Gregersen, P. L., Smedegaard-Petersen, V., and Collinge, D. B. 1992. cDNA cloning and characterization of two barley peroxidase transcripts induced differentially by the powdery mildew fungus Erysiphe graminis. Physiol. Mol. Plant Pathol. 40:395-409.

Tiburzy, R., and Reisener, H. J. 1990. Resistance of wheat to Puccinia graminis $\mathrm{f}$. sp. tritici: Association of the hypersensitive reaction with the cellular accumulation of lignin-like material and callose. Physiol. Mol. Plant Pathol. 36:109-120.

Vera, P., Tornero, P., and Conejero, V. 1993. Cloning and expression analysis of a viroid-induced peroxidase from tomato plants. Mol. Plant-Microbe Interact. 6:790-794.

Walter, M. H. 1992. Regulation of lignification in defense. Pages 327-352 in: Genes Involved in Plant Defense. T. Boller and F. Meins, eds. Springer-Verlag, New York.

Welinder, K. G. 1985. Plant peroxidases. Their primary, secondary and tertiary structures, and relation to cytochrome peroxidase. Eur. J. Biochem. 151:497-504.

Young, S. A., Guo, A., Guikema, J. A., White, F. F., and Leach, J. E. 1995. Rice cationic peroxidase accumulates in xylem vessels during incompatible interactions with Xanthomonas oryzae pv. oryzae. Plant Physiol. 107:1333-1341. 